\title{
Public health history
}

\begin{abstract}
ADDICTION
Contested term used to describe compulsive drug taking. First in use to denote a disease requiring psychiatric treatment in the early 20th century, replacing older language of "habit", "inebriety", "morphinomania". Primarily focused on alcohol and drugs initially. Recent discussion of nicotine addiction symbolises ownership by public health as well as by psychiatry.
\end{abstract}

\section{COMMUNITY HEALTH}

Community health workers were organised in the countries of the developing world after Alma Ata's (1978) focus on primary health care (PHC) and WHO's Health for All by the Year 2000 gave public health a higher profile at the international level. Conceptual and practical confusion between PHC and public health, as in the UK, with tensions between general practitioners (GPs) and public health personnel.

\section{COMMUNITY MEDICINE}

Concept developed by social medicine academics in the UK to provide training in health administration and epidemiology for the effective administration of health services. Critics argued that, when implemented in the 1970s, the loss of the medical officer of health meant that the relationship with the local community was lost. Distinct from community health (see above).

\section{EPIDEMIOLOGY}

The science of disease in populations. In the 19th century, the epidemiology of infectious disease and vital statistics were central parts of the public health curriculum. After the second world war, epidemiology expanded its remit within public health to include chronic disease and the concept of "relative risk" was born.

\section{DISEASE}

The health of the public was undermined by epidemic infectious diseases like cholera, which ravaged industrialising countries in the 19th century. After the second world war, the greater prevalence of chronic, degenerative disease began to characterise high and middle income populations. New and re-emerging infectious disease became a global health problem at the close of the 20th century.

\section{EUGENICS}

The science of improving the quality of the human race, especially by selective breeding. Prominent in the early 20th century. Contrasted the declining fertility of the middle class with the high fertility of the "residuum" in large towns. Positive and negative versions, which attracted a wide range of political and social reform opinion.

\section{GERM THEORY/BACTERIOLOGY}

The bacteriological revolution ascribed the origins of infectious disease to specific organisms. Pasteur demonstrated the existence of bacteria that communicated disease and Koch identified the causative agent of tuberculosis. Germ theory identified the underlying cause of disease as the entry of microorganisms in the body. For public health this meant a change of focus from environmental to individual solutions.

\section{HEALTH EDUCATION}

The individual focus in turn of the century public health led to increased reliance on educating individuals, often mothers. The revival of individual arguments for prevention and lifestyle in the 1970s saw further emphasis on health education, often carried out through mass media "single issue" campaigns. Their efficacy in changing behaviour was questioned.

\section{HEALTH PROMOTION}

Term used to describe positive strategy for improving health based on framework laid out in international documents such as WHO's Health for All (1981) and the Ottawa Charter (1986). Implies intersectoral cooperation, marketing techniques for health, broader environmental emphasis. Often confused with health education.

\section{HYGIENE}

Originally meant practices and principles for maintaining health-that is, moderation, cleanliness. Now interchangeable with "sanitary", its meaning is restricted to prevention of infection. In previous centuries the term was more expansive, encompassing ideas of moral and racial contamination. Social or racial hygiene described interventions like forced sterilisation of the "unfit".

\section{INOCULATION/VACCINATION}

Deliberate introduction of smallpox matter through the skin or mucous membrane, to confer immunity, introduced from the Middle East into England in 1717. Jenner published the account of his first experiment with vaccination in 1798. Important, but controversial public health procedure, with history of working class opposition because of inequities and safety issues.

\section{MATERNITY AND CHILD WELFARE}

Maternal and child welfare was central to the individualised public health of the turn of the 19th century. Many countries established child welfare clinics. In the UK the role of the health visitor was important, advising mothers and monitoring infant health, an intrusion that was often resented.

\section{MEDICAL POLICE}

Promoted from late 18th century by physician Johann Peter Frank. A state administered system of health inspectors with powers to quarantine, disinfect, and cleanse. Aimed to support aims of absolutist rulers to boost population numbers, ensuring fit labour force and military conscripts. Policing model remained important in 19th century, as with British medical officer of health.

\section{NEW PUBLIC HEALTH}

Term subject to confusion, used to denote different versions of recent public health. Lifestyle public health of 1970s, with reference to Lalonde Report, emphasised individual responsibility for prevention of ill health. Limitations of this approach led to new public health of the 1980s focusing on environmental concerns and health inequality. More recent changes stress role of clinical prevention and genetics.

\section{OCCUPATIONAL HEALTH}

Occupational diseases more prevalent because of the industrial revolution. European states introduced legislation to regulate the health and safety of factory work in the 19th century. Systems of factory inspection developed in Britain and Prussia. Occupational health an important driving force behind social insurance systems, but tended to remain separate from mainstream public health. 


\section{SANITARIANISM/SANITARY MOVEMENT}

Sanitary movement launched in European countries in the 1820s. Inspired in Britain by Benthamism, and emphasised the need for "experts" in the service of government. Sanitarianism aimed to reduce environmental pollution in the interests of human health. Preventable disease was dependent on environmental factors such as impure air and water supply.

\section{SOCIAL MEDICINE}

Term used in some countries to denote health as a democratic right with disease caused by socioeconomic factors, but also used with biological explanations of same. Post second world war academic discipline aiming to link the planning of health and social services to the needs of the population. Failed to influence medical education or public health practice, but retained symbolic importance.

\section{URBANISATION}

Britain underwent rapid urbanisation from the 18th century. Migration to industrial centres was not met by infrastructure development, creating dire conditions of overcrowding, poor housing, and sanitation. The impact of epidemic disease and poor health status of the urban proletariat established enduring link between urban life and ill health.

\section{VITAL STATISTICS}

Initially christenings and burials were recorded in Bills of Mortality, which sought to monitor plague deaths in 17th century London. The 1830s saw more extensive compilation of statistics of births and deaths in countries like France and the UK, where the work of William Farr at the General Register Office provided data for sanitary reformers.

\section{ACKNOWLEDGEMENTS}

We are grateful to our colleagues in the history group at LSHTM for suggesting terms and especially to Sarah Mars for detailed comments. Our thanks are due to Ingrid James for secretarial assistance.

V Berridge, K Loughlin, London School of Hygiene and Tropical Medicine London

Correspondence to: Professor V Berridge, Health Promotion Research Unit, Department of Public Health and Policy, London School of Hygiene and Tropical Medicine, Keppel Street, London WCIE 7HT, UK; Virginia.Berridge:@lshtm.ac.uk

\section{GENERAL REFERENCES}

Fee E, Acheson R. A history of education in public health. Health that mocks the doctors' rules. Oxford: Oxford University Press, 1991.

Hamlin C. Public health and social justice in the age of Chadwick: Britain, 1800-1854. Cambridge: Cambridge University Press, 1998.

Harrison M. Public Health in British India. Anglo-Indian Preventive Medicine,
1859-1914. Cambridge: Cambridge University Press, 1994.

Lewis J. What Price Community Medicine? The Philosophy, Practice and Politics of Public Health since 1919. Brighton: Harvester/ Wheatsheaf, 1986.

Petersen A, Lupton D. The New Public Health. Health and Self in the Age of Risk. London: Sage, 1996.

Porter D, ed. The History of Public Health and the Modern State. Amsterdam: Rodopi, 1994.

Porter D. Health, Civilisation and the State. A history of public health from ancient to modern times. London: Routledge, 1999.

Rosen G. A History of public health. Expanded edition with introduction by Elizabeth Fee. Baltimore: Johns Hopkins University Press, 1993.

Rosenberg C. Explaining epidemics and other studies in the history of medicine. Cambridge: Cambridge University Press, 1992.

Webster C, ed. Caring for health. History and diversity. 3rd edn. Buckingham: Open University Press, 2001.

Weindling $\mathrm{P}$, ed. The social history of occupational health. Beckenham: Croom Helm, 1985.

Worboys M. Spreading germs: disease theories and medical practice in Britain, 18651900. Cambridge: Cambridge University Press, 2000. 